\title{
PELATIHAN PEMASARAN ONLINE BAGI KELOMPOK USAHA BERSAMA (KUB) "SRIKANDI"
}

\author{
Emaya Kurniawati ${ }^{1}$, Aprih Santoso ${ }^{2}$, Sri Yuni Widowati ${ }^{3}$ \\ ${ }^{1}$ Fakultas Ekonomi Universitas Semarang \\ email: kurniawati_ema@yahoo.co.id \\ ${ }^{2}$ Fakultas Ekonomi Universitas Semarang \\ email: aprihsantoso@usm.ac.id \\ ${ }^{3}$ Fakultas Ekonomi Universitas Semarang \\ email: sriyuniw@usm.ac.id
}

\begin{abstract}
Members of Kelompok Usaha Bersama (KUB) "SRIKANDI" which is engaged in the health and food business so far its sales have not experienced an increase because its marketing is only carried out in the surrounding area or sold to close relatives and their own families, it requires a more productive marketing by using technological advances namely on-line marketing that utilizes the networkinternet to promote their products. The purpose of this Community Service program is to carry out online marketing training for Kelompok Usaha Bersama (KUB) "SRIKANDI". The results of on-line marketing training are members of Kelompok Usaha Bersama (KUB) "SRIKANDI" that can produce marketing and promotion online for their production results widely so as to increase sales which will also have an impact on increase income of Kelompok Usaha Bersama (KUB) "SRIKANDI".
\end{abstract}

Keywords: marketing, online, training

\begin{abstract}
ABSTRAK
Anggota Kelompok Usaha Bersama (KUB) "SRIKANDI" yang bergerak dibidang bisnis makanan dan minuman kesehatan selama ini penjualannya tidak mengalami peningkatan karena pemasarannya hanya dilakukan di wilayah sekitarnya atau dijual kepada kerabat dekat dan keluarganya sendiri, maka diperlukan suatu pemasaran yang lebih produktif dengan menggunakan kemajuan teknologi yaitu dengan pemasaran secara online yang memanfaatkan jaringan internet untuk mempromosikan hasil produksinya. Tujuan kegiatan Pengabdian Kepada Masyaraka ini adalah melaksanakan pelaltihan pemasaran secara online bagi Kelompok Usaha Bersama (KUB) "SRIKANDI". Adapun hasil pelatihan pemasaran secara online adalah anggota Kelompok Usaha Bersama (KUB) "SRIKANDI" dapat menghasilkan pemasaran dan promosi secara online atas hasil produksinya secara luas sehingga dapat meningkatkan penjualan yang berdampak pula pada peningkatan pendapatan Kelompok Usaha Bersama (KUB) "SRIKANDI".
\end{abstract}

Kata Kunci: pemasaran, online, pelatihan 


\section{PENDAHULUAN}

Usaha kecil menengah terbukti mampu menampung 99,45 persen dari total tenaga kerja atau 73,24 juta tenaga kerja (Marimbo, 2008). Salah satu hal yang penting dalam menjalanlan sebuah usaha adalah konsep pemasaran baik peluang usaha baru maupuan usaha yang telah lama berjalan. Dalam konsep pemasaran. Untuk dapat meningkatkan hasil penjualan tentunya pelaku usaha harus pandai dalam memasarkan produknya dari mulai promosi sampai menjual produknya. Sejalan dengan teknologi informasi yang semakin berkembang pilihan usaha kecil menengah untuk go online sudah semakin terbuka. Media sosial internet merupakan sumber informasi yang paling banyak digunakan dalam perusahaan. Karena internet dapat menjangkau semua wilayah, potensial dan cepat untuk menyampaikan berbagai informasi secara universal, berkualitas, dan hampir tidak memerlukan cost (Adelaar, 2000).

Semakin banyak pelaku usaha khususnya UKM melakukan kontent yang berisi mengenai produknya semakin besar peluang orang lain mengetahui apa yang anda tawarkan. Jika mereka menyukainya, ini akan menjadi kontent viral dimana akan banyak orang yang membicarakan mengenai produk yang ditawarkan. Dengan kemajuan teknologi atau pemasaarn secara online pelaku usaha dalam mempromosikan dan memasarkan hasil produknya tidak harus bertemu langsung dengan konsumen ataupun bertatap muka, sehingga dalam hal ini dapat menghemat waktu dan biaya. Sejalan dengan berkembangnya internet, muncul pemahaman baru mengenai paradigma pemasaran berupa konsep pemasaran modern yang berorientasi pada pasar atau konsumen atau revolusi pemasaran berupa electronic marketplace (Arnott dan Bridgewater, 2002; Bakos, 1999).

Usaha Mikro Kecil (UMK) keseluruhan di Kecamatan Cepiring berjumlah 35 usaha, dari jumlah UMK di Kecamatan Cepiring tersebut ada satu Kelompok Usaha Bersama (KUB) yang berjumlah 17 anggota dengan nama Kelompok Usaha Bersama (KUB) "SRIKANDI", yang kegiatan usahanya meliputi: usaha katering, usaha camilan dan kerajinan tangan. Dengan telah terbentuknya kelompok usaha tersebut, diharapkan unit usaha dapat berkembang seiring dengan berkembangnya kelompok usaha tersebut. Salah satu tolok ukur berkembangnya kelompok usaha adalah adanya motivasi dari anggotanya umtuk meningkatkan dan mengembangkan usahanya. Hal ini terbukti semakin banyak jumlah dan jenisnya produk-produk yang dihasilkan oleh Kelompok Usaha Bersama (KUB) "SRIKANDI".

Dari Anggota Kelompok Usaha Bersama (KUB) "SRIKANDI" selama ini dalam melakukan pemasaran dari hasil produksinya hanya dijual di toko-toko wilayah sekitarnya atau di kabupaten Kendal dan mengikuti bazar-bazar yang diadakan oleh Pemerintah Kabupaten Kendal. Dari hasil survey diketahui bahwa pelaku usaha anggota Kelompok Usaha Bersama (KUB) "SRIKANDI" Kecamatan Cepirirng Kabupaten Kendal belum mengetahui cara mengenalkan dan menjual produk secara online. 
Untuk meningkatkan volume penjualan bagi anggota Kelompok Usaha Bersama (KUB) "SRIKANDI" maka perlu mencoba untuk melakukan pemasaran secara online sehingga produknya tidak hanya di wilayah Kabupaten Kendal saja tetapi bisa ke semua wilayah yang terjangkau internet yang akan mengenal produk tersebut. Adapun permasalahan yang ada pada Kelompok Usaha Bersama (KUB) "SRIKANDI" terletak pada faktor keterbatasan pengetahuan dan kemampuan dari sumber daya manusianya dalam mempromosikan produk dan meningkatkan volume penjualan produk yang telah dihasilkan, yang mana selama ini pemasaran hanya dilakukan di wilayah Kabupaten Kendal dan untuk promosi tidak pernah dilakukan. Hal ini menyebabkan sangat sulit dalam hal perkembangan usahanya. Untuk itu, perlu diberdayakan dengan diberikan pelatihan tentang bagaimana cara mempromosikan dan menjual produk secara online dengan jaringan internet. Yang pada akhirnya dapat meningkatkan penjualan dan akan mendatangkan keuntungan lebih banyak dan sekaligus akan dapat meningkatkan pendapatan (memperbesar modalnya) anggota Kelompok Usaha Bersama (KBU) "SRIKANDI".

Melihat serta mencermati hal tersebut maka Tim Pengabdian Kepada Masyarakat Fakultas Ekonomi Universitas Semarang (USM) tergerak untuk berpartisipasi memberikan pelatihan pemasaran secara online kepada Kelompok Usaha Bersama (KBU) "SRIKANDI" agar produknya lebih dikenal dan dapat meningkatkan penjualan yang berpengaruh terhadap pendapatan, yang akhirnya usahanya berjalan dengan baik dan maju. Hal ini juga sesuai dengan Maheswara, dkk (2016) yang menyatakan bahwa jumlah penjualan berpengaruh terhadap pendapatan UKM sektor perdagangan.

\section{METODE PELAKSANAAN}

Metode pelatihan yang diterapkan oleh Tim Pengabdian Kepada Masyarakat Fakultas Ekonomi Universitas Semarang (USM) adalah dengan menggunakan hand phone / lap top dari anggota Kelompok Usaha Bersama (KBU) "SRIKANDI" masing-masing untuk melakukan promosi atau menjual produknya dengan secara online dengan memanfatkan internet. Dalam melakukan pemasaran online system yang digunakan adalah menawarkan pemasaran online dengan BUKALAPAK dan Face book dengan cara membuat akun face book yang bernama Kelompok Usaha Bersama (KUB) "SRIKANDI" dengan menampilkan foto-foto hasil produksi yang berupa makanan kecil dan minuman kesehatan.

\section{Evaluasi Awal Kegiatan}

Kegiatan tahap ini mengevaluasi kegiatan usaha yang telah dilakukan saat ini dan penyelesaian permasalahan yang dijadikan prioritas. Kegiatan usaha untuk menjual produk yang dihasilkan pada saat ini masih dijual di toko-toko di wilayah Kabupaten Kendal dan teman atau saudara dekat. Adapun metode yang dilakukan adalah melalui wawancra yaitu 
dengan cara bertanya langsung kepada anggota Kelompok Usaha Bersama (KUB) "SRIKANDI".

\section{Penyuluhan dan Pelatihan}

Kegiatan tahap ini bertujuan untuk meningkatkan ketrampilan sumber daya manusia dari Kelompok Usaha Bersama (KUB) "SRIKANDI". Kegiatan ini dilaksanakan dengan menyuluh dan melatih tentang cara melakukan pemasaran secara online. Dengan cara ini Kelompok Usaha Bersama (KUB) "SRIKANDI" dapat lebih intensif dalam menerima materi yang diberikan dan mampu mengembangkan usaha. dengan meningkatkan jumlah penjualan.

\section{HASIL DAN PEMBAHASAN}

Dalam pelaksanaan kegiatan Pengabdian Kepada Masyarakat, Tim Pengabdian Kepada Masyarakat Fakultas Ekonomi Universitas Semarang (USM) memanfaatkan waktu pelaksanaan dengan efisien dan efektif sehingga hasil yang diharapkan dapat tecapai. Pelaksanaan pengabdian pelaksanaan Pengabdian Kepaada Masyarakat kepada Kelompok Usaha Bersama (KUB) "SRIKANDI" ini dilaksanakan pada: Kamis, 24 Januari 2019.

Kegiatan Pengabdian memberikan pelatihan tentang bagaimana melakukan penjualan secara online untuk mendongrak tingkat penjualan dan untuk menunjang kesuksesan usaha bagi Kelompok Usaha Bersama (KUB) "SRIKANDI" di Kecamatan Cepiring Kabupaten Kendal ini telah terlaksana dengan sukses. Hal ini terbukti dengan antusiasnya peserta mengikuti tanya jawab dari materi yang sudah disampaikan khususnya bagaimana melakukan pemasaran secara online dalam hal ini dengan menggunakan grab food, sehingga produknya dapat lebih dikenal oleh masyarakat luas dan juga dapat meningkatkan penjualan yang akhirnya membuat pendapatan anggota Kelompok Usaha Bersama (KUB) "SRIKANDI" semakin meningkat.

Kendala yang masih dihadapi anggota Kelompok Usaha Brsama (KUB) "SRIKANDI" untuk dapat memasarkan produknya di grab food yang belum dapat dipenuhi dari sebagian anggota Kelompok Usaha Bersama (KUB) "SRIKANDI" adalah belum tersedianya tempat berjualan yang menarik untuk memajang ataupun menyimpan hasil produknya.

Adapun faktor-faktor yang mendorong Anggota Kelompok Usaha Bersama (KUB) "SRIKANDI" di Kecamatan Cepiring Kabupaten Kendal ini adalah:

1. Para peserta ingin produk yang dihasilkan laku dipasaran dan lebih dikenal oleh masyarakat luas sehingga usahanya dapat bertahan dan berkembang.

2. Para peserta ingin lebih lebih mudah memasarkan hasil produknya dengan lebih ekonomis dan praktis.

Pada awal kegiatan yaitu memberikan penjelasan tentang pemasaran produk karena walaupun dapat menghasilkan suatu produk yang berkualitas 
tetapi tidak dapat memasarkan maka tidak ada artinya produknya yang telah dibuat dengan mengeluakan tenaga dan biaya.

Adapun Materi Penyuluhan Pemasaran online yaitu:

1. Memberikan penjelasan tentang pemasaran online serta manfaat yang diperoleh dengan menggunakan pemasaran secara online. Berikut dokumenntasi kegiatan:

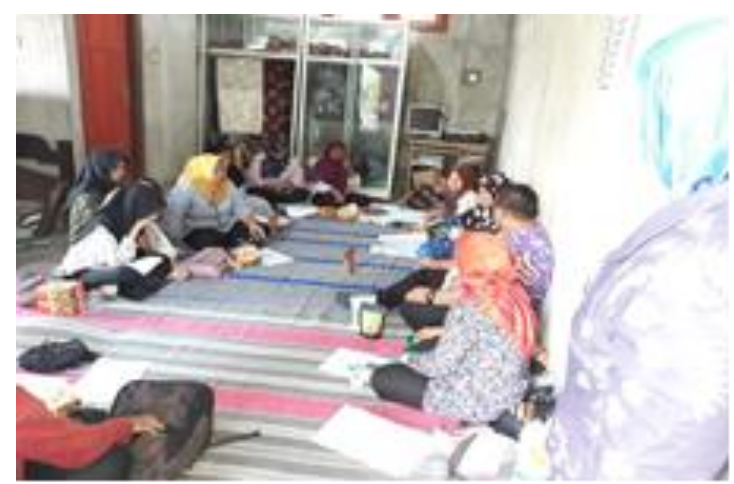

Gambar 1. Proses penyuluhan

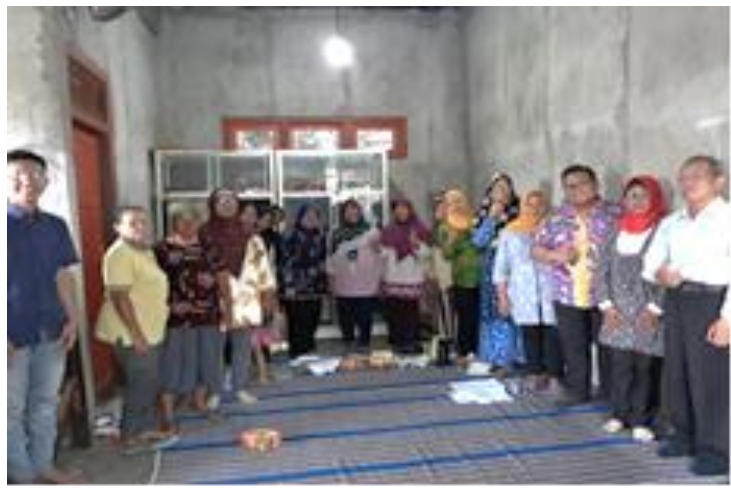

Gambar 2. Foto berama Pasca penyuluhan

2. Pemasaran online yang diberikan adalah membantu anggota kelompok usaha bersama untuk bisa memasarkan secara online, cara yang didisampaikan adalah dengan mendaftarkan di gofood dan menawarkan lewat facebook masing-masing anggota yang sudah memiliki facebook dan akan dibuat facebook khusus anggota Kelompok Usaha Bersama (KUB) "SRIKANDI" yang menawarkan produk-produknya. Beberapa contoh hasil produksi yang sudah siap dipasarkan secara online sebagai berikut: 

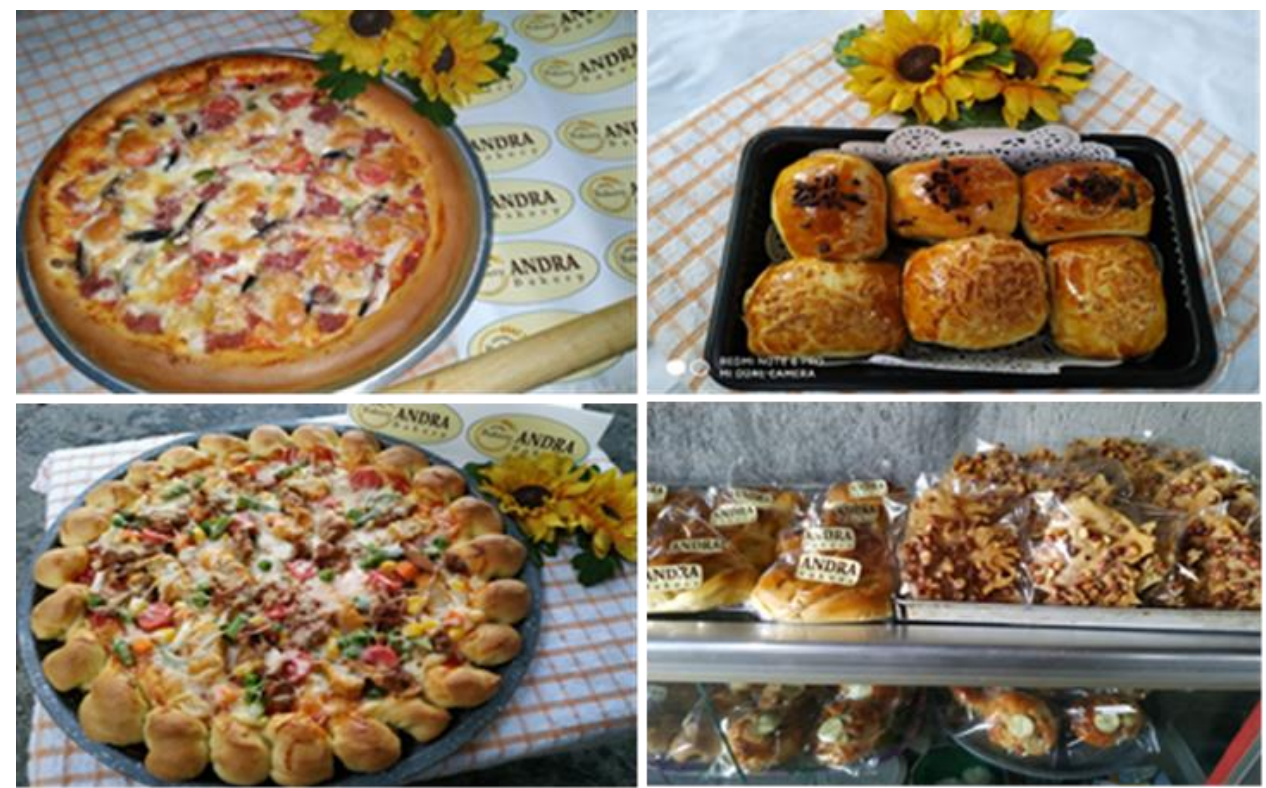

Gambar 3. Hasil Produksi

\section{KESIMPULAN}

Pelaksanaan Pengabdian Kepada Masyarakat tentang penyuluhan dan pelatihan pemasaran online bagi pelaku usaha anggota Kelompok Usaha Bersama (KUB) "SRIKANDI" di Kecamatan Cepiring Kabupaten Kendal sangat membantu pelaku usaha dalam memasarkan produknya yang sebagian besar menghasilkan produk makanan ringan dan kue-kue serta minuman kesehatan.

Dengan pemasaran online anggota Kelompok Usaha Bersama (KUB) "SRIKANDI" tidak lagi mengalami kesulitan dalam memasarkan produknya yang mana selama ini kurang dikenal oleh masyarakat luas khususnya di wilayah Kabupaten Kendal.

\section{UCAPAN TERIMA KASIH}

Tim Pengabdian Kepada Masyarakat Fakultas Ekonomi Uniersitas Semarang (USM) menghaturkan banyak terima kasih kepada anggota Kelompok Usaha Bersama (KUB) 'SRIKANDI' Kecamatan Cepiring Kabupaten Kendal yang sudah berpartisipasi sebagai peserta dan bekerjasama untuk melakukan kegiatan pengabdian kepada masyarakat yang berupa pelatihan pemsaran online. Tidak terkecuali, Tim Pengabdian Kepada Masyarakat Fakultas Ekonomi Uniersitas Semarang (USM).

\section{DAFTAR RUJUKAN}

Adelaar, Thomas. (2000). Electronic Commerce and Implifications for market Structure: The Example of the Art and Antiques Trade. Journal of Computer-Mediated Communication, 5 (3).

Arnott, David C. dan Susan Bridgewater. (2002). "Internet, Interaction 
and Implications for Marketing," Marketing Intelligence dan Planning, 20 (2):86-95

Bakos, Yannis dan Brynjolfsson, Erik (1999). Bundling information goods: Pricing, profits, and efficiency. Management Science, 45 (12): 16131630.

Maheswara, AANG; Setiawarna, NJ; Saskara, IAN. (2016). Analisis FaktorFaktor Yang Mempengaruhi Pendapatan Ukm Sektor Perdagangan Di Kota Denpasar. E-Jurnal Ekonomi dan Bisnis Universitas Udayana 5.12 (2016): 4271-4298. ISSN : 2337-3067.

Marimbo. (2008). Ayo ke Bank Dapatkan Kredit UMKM. PT. Eka Media Komputindo. Jakarta. 